\title{
Siliceous raw material consumption during the late Upper Palaeolithic in "El Pirulejo", South of Iberia (Priego, Córdoba)
}

\author{
Isabel Cánovas Calle ${ }^{1}$, María Dolores Simón Vallejo ${ }^{1,2,3}$, Lydia Calle Román ${ }^{1}$, \\ Victoria Aranda Sanchez ${ }^{1}$, Rubén Parrilla Giraldez ${ }^{1}$, Antonio Tarriño Vinagre ${ }^{4}$, \\ Miguel Cortés Sánchez ${ }^{1,2,3}$
}

1. Grupo de Investigación TELLUS. Prehistoria y Arqueología en el Sur de Iberia (HUM-949). Departamento de Prehistoria y Arqueología. Facultad de Geografía e Historia, University of Seville. c/. Doña María de Padilla s/n.

41004. Seville, Spain. Email: Cánovas Calle: isacanovasc@gmail.com; Vallejo: simonmd63@gmail.com;

Calle Román: arqueolydi83@hotmail.com; Aranda Sanchez: victoriaarandasanchez@gmail.com;

Parrilla Giraldez: mrruben99@msn.com; Cortés Sánchez: mcortes@us.es

2. University of Seville. c/. Doña María de Padilla s/n. 41004. Seville, Spain.

3. Interdisciplinary Center for Archaeology and Evolution of Human Behavior, Universidade do Algarve, Portugal.

4. Centro Nacional de Investigación sobre la Evolución Humana (Burgos, España). Paseo Sierra de Atapuerca, 3, 09002 Burgos, Spain. Email: andoni.tarrinno@gmail.com

\begin{abstract}
:
This work presents the first results about the use of siliceous raw materials by the hunter-gatherer societies during the Late Glacial in the level 5 of El Pirulejo. El Pirulejo is located within the municipality of Priego de Córdoba (Córdoba, Spain).

The archaeological level P/5 is classified as a Solutrean, according to the technological analysis of the lithic assemblage. The methodology used about the raw material is divided into four phases. During this first phase, we carried out a sampling analysis of local primary and secondary outcrops in the proximity of the site, over an area of $20 \mathrm{~km}$ from the site. We also performed a macroscopic and petrographic analysis of selected samples. In these phase, we describe the Veleta Formation, wich represents the main siliceous outcrop closest to the site. Once the local flint was characterized, it was compared to the lithic industry assemblage of level $\mathrm{P} / 5$, with the intention of observing the management and exploitation of local flint associated to knapping activities. As a result of the assemblage analysed so far, we have ruled out local operations on these chert samples and propose an area of exploitation of lithic resources that will exceed 20 kilometres around the site. We ruled out that the Veleta Formation provided a source of lithic supply for the hunter-gatherer societies.
\end{abstract}

Keywords: Tardiglacial; raw materials; Veleta Formation; flint; management

Published by the School of History, Classics and Archaeology, University of Edinburgh ISSN: 2055-0472. URL: http://journals.ed.ac.uk/lithicstudies/

This work is licensed under a Creative Commons Attribution 2.5 UK: Scotland License. 


\section{Introduction}

Studies on raw materials in archaeological assemblages of the Palaeolithic in Andalusia (South of Spain), have been limited and isolated. Works related to the supply of flint in prehistoric societies have also been few in number Late Prehistory, (Cabrero 1981; Cortés et al. 2008; Lozano et al. 2010; Morgado et al. 2009; Morgado et al. 2011; Morgado et al. 2011; Nocete Calvo, 2001; Rodríguez-Tovar et al. 2010; Vallespí et al. 1988).

This work represents one of the first studies on the localization and characterization of geological siliceous outcrops in Andalusia susceptible have been exploited by Upper Palaeolithic societies.

Our main goal was to locate and describe the potential siliceous sources available in a regional radius of $20 \mathrm{~km}$ around the Late Upper Palaeolithic occupations of El Pirulejo site (Córdoba). The petrographic analysis of the archaeological materials was contrasted with the geological information around the site in order to define which raw materials were used and their outcropping area.

This study focuses on layer $\mathrm{P} / 5$, of El Pirulejo, and also presents the technomorphological and functional information available so far. This enables an initial insight into the dynamics governing the organization, exploitation, circulation and abandonment of the lithic materials (Mangado 2006).

\subsection{The site}

El Pirulejo site is a rock shelter built on travertine within the municipality of Priego de Córdoba (Córdoba, Spain), located at 580 m ASL, with geographic coordinates of $37^{\circ} 26^{\prime} 32^{\prime \prime}$ and $4^{\circ} 11^{\prime} 15^{\prime \prime}$ (Figure 1).

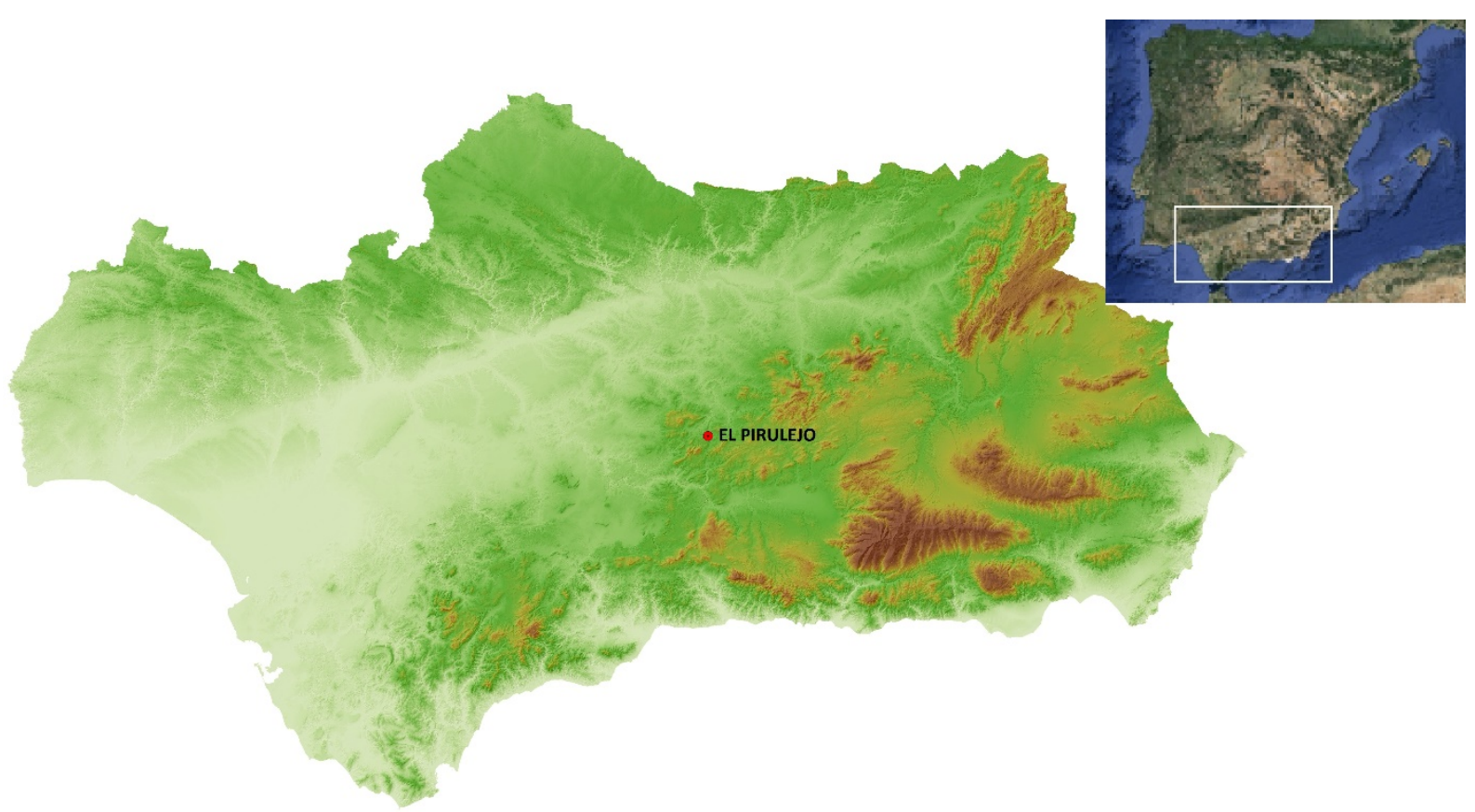

Figure 1. Location map of “El Pirulejo” site. (Compiled by authors.)

From a geological perspective, El Pirulejo belongs to the external sub-Baetic areas. In this area, all the flint outcrops catalogued on the geological map correspond to the Jurassic. On the other hand, from a physiographic point of view, the studied zone presents a SE-NW area consisting of a mountainous strip forming the regional interfluve, with mountain elevations such as the Cabra Massif (around 1,000 m ASL), the Carcabuey Pass (small 
mountains, hills and foothills) and south-central alignments between Rute and Priego (Cortés 2008).

Similarly, we find the Priego-Alcaudete depression (head of the Salado River, confluent with the Guadajoz River) and the foothills from the West (Montilla countryside, Genil River and its tributaries Cabra and Anzur) (Cortés et al. 2008).

El Pirulejo is associated to the travertines of Priego de Córdoba. That lithochemical construction was formed by carbonated springs located at higher altitudes that spread through various loamy and detrital materials (Díaz del Olmo \& Álvarez 1995). The upwelling would cease to be active at a certain time and, once inactive, it would shape a medium-sized cavity showing a parallel gallery or a half open rock shelter in front of the travertine that was recurrently used by hunter-gatherer groups at the end of the Pleistocene and the Early Holocene.

\subsection{Chrono-culture sequence}

The stratigraphic sequence known so far is made up of 6 archaeological levels (Cortés et al. 2008). The superficial level (P/S) provided materials corresponding to the Contemporary Period, while stratum P/1 contains materials assigned to the Late Prehistory (Cortés 2007) (Figure 2, and Table 1).

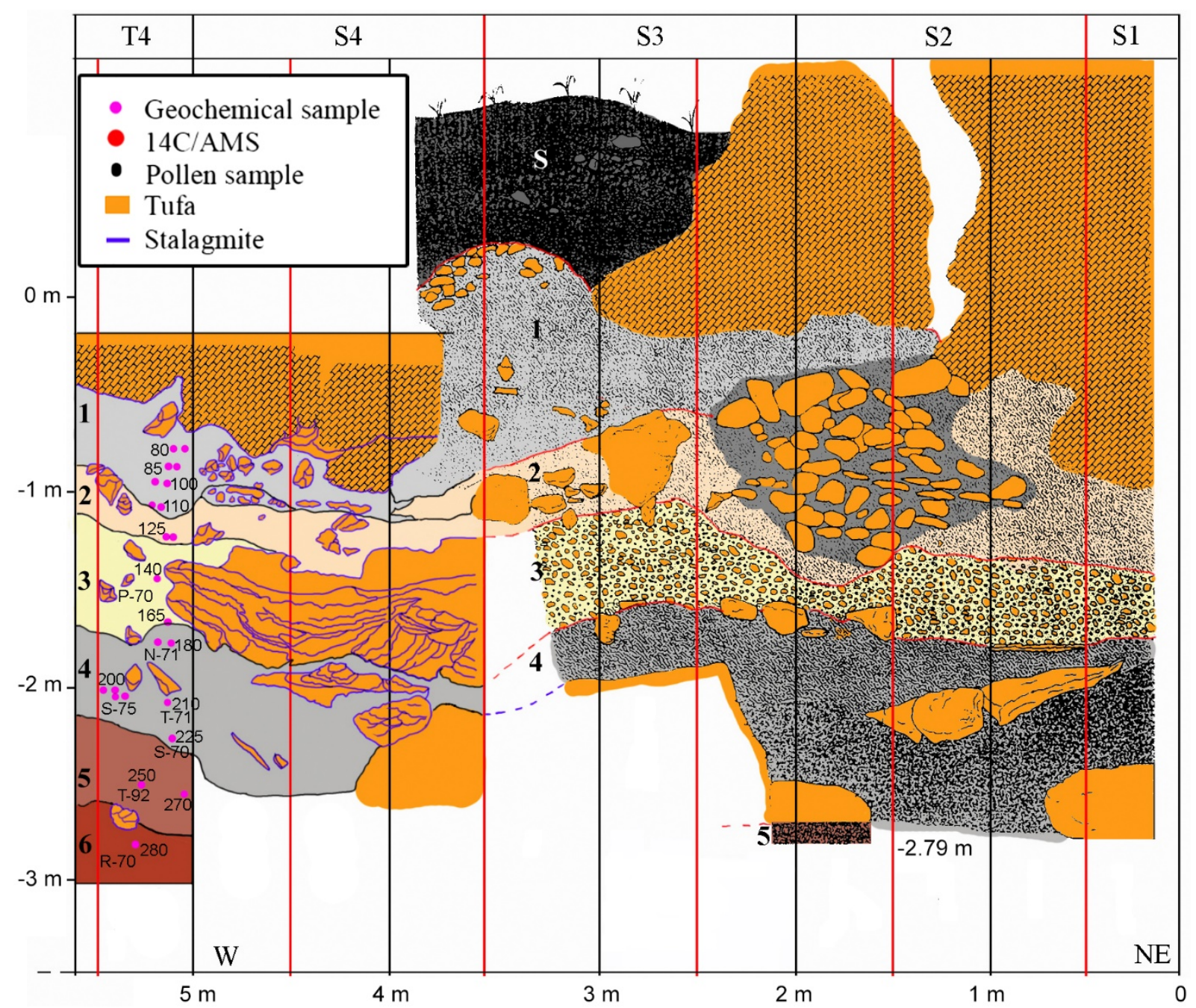

Figure 2. Stratigraphic column of El Pirulejo site (Cortés 2001).

On the other hand the stratigraphical series fits within the Late Upper Palaeolithic. 
Table 1. Chronological and culture sequence

\begin{tabular}{|c|c|c|c|c|c|}
\hline \multicolumn{2}{|c|}{ Stratum } & BP (14C) & C. B.P & c. cal BP & Techno-Cultural Ascription \\
\hline \multicolumn{2}{|c|}{$\mathrm{P} / \mathrm{S}$} & - & $>1000$ & - & Modern-Contemporary Age \\
\hline \multicolumn{2}{|l|}{$P / 1$} & - & $>1000$ & $<12800$ & Recent prehistory and Bronze Age \\
\hline \multicolumn{2}{|l|}{$\mathrm{P} / 2$} & - & $10000-11000$ & $12800-14000$ & Late Mediterranean Magdalenian \\
\hline \multicolumn{2}{|l|}{$P / 3$} & - & $11000-12500$ & $14000-17000$ & Upper Mediterranean Magdalenian \\
\hline \multirow[t]{2}{*}{$P / 4$} & $A, B, C$ & $13500-14500$ & $13500-14500$ & $16000-17900$ & Middle Mediterranean Magdalenian \\
\hline & $\mathrm{D}$ & - & - & - & - \\
\hline \multicolumn{2}{|l|}{$P / 5$} & - & $>15000$ & $>18000$ & Upper Palaeolithic \\
\hline \multicolumn{2}{|l|}{$P / 6$} & - & - & - & Upper Palaeolithic \\
\hline
\end{tabular}

\section{Materials and Methods}

\subsection{Materials}

The analysed artefacts proceed from level $\mathrm{P} / 5$, totalizing an excavated area of $3 \mathrm{~m}^{2}$. It is a level of much cemented clay sediment, of brecciated appearance and beige colours to ceiling that amalgams bone remains and lithic industry.

The material recovered from level $\mathrm{P} / 5$ consists of 11,743 lithic pieces, of which we have analysed the lithic assemblage made of flint, turning out a total of 11,635 pieces. 20 of these pieces have been analysed in thin-section.

This has enabled progress in the knowledge of raw material management during the regional Upper Palaeolithic.

Table 2. Analysed lithic assemblage. Level P/5 of El Pirulejo.

\begin{tabular}{lcc}
\hline Type & No & \%* \\
\hline Flakes & 395 & 30,95 \\
Blades & 15 & 1,17 \\
Bladelets & 572 & 44,82 \\
Cores reconditioning & 170 & 13,32 \\
Retouched Tools & 124 & 9,71 \\
Cores & 41 & - \\
Chunk + chips & 18 & - \\
Debris & 10300 & - \\
\hline Total & $\mathbf{1 1 6 3 5}$ & $\mathbf{1 0 0}$ \\
\hline
\end{tabular}

\subsection{Methods}

The potential areas where the flint is located have been delimited from the local and regional geology, based on the geological literature.

The selected area was surveyed using the available geological maps of the area (Sheet 989, Lucena, and Sheet 990, Alcalá la Real) and considering the bibliographic references of the primary siliceous outcrops in this area.

The geological prospections were carried out on the primary flint outcrops in an area of 20 kilometres from the site. The collection of geological samples will be accompanied by a systematic description of the location GPS positioning, using Garmin Etrex30X GPS equipment, as well as the geological characterization of the outcrop (Tarriño 2006).

The Salado river basin, that contains flints in secondary position, was the second area prospected. 
The macroscopic analysis was carried out on the archaeological flint artefacts excavated from level P/5. A binocular loupe was used (Olympus SZX10) with the purpose of establishing siliceous varieties based on macroscopic characteristics such as colour, texture, translucency, shine, cortex, patina, inclusions and weathering (Tarriño 2006: 125).

Once the siliceous varieties of the archaeological assemblage was established, 15 thin sections were made to establish petrographic characteristics of each variety. The microscopic analysis was performed by a Nikon Eclipse E200.

In order to establish parallels between the archaeological and geological flint, the same analytical method was carried out. A total of 24 geological samples were observed macroscopically and 6 of them where analysed microscopically. The petrographic analysis was carried out systematically following the database designed and published by Tarriño (2001).

In the next work, a petrologic study will be extended by $\mathrm{X}$ ray diffraction analysis-and it will be completed with a geochemical analysis by X-ray fluorescence. (Tarriño 2001)

\section{Results}

\subsection{Geological context of the siliceous outcrops}

The primary flint outcrops we studied as potential abiotic resource catchment areas make up part of the Sub-external Baetic System.

All the territories that form the Baetic System (internal and external areas as well as the Gibraltar Complex), include various techto-stratigraphic units derived from the pre-existing palaeogeographic territories, evolved during the Mesozoic Era to the Phynopaleozoic megacontinent of Pangea, formed during the extension of the Central Atlantic platform (Vera 1969). (Figure 3).

The Internal Areas of the System shows a deep deformation which affects the bedrock, accompanied by metamorphism, whereas the External Areas are located on the edges of the European and African plates. (Garcia et al. 1985).

García Dueñas et al. (1980) divides the External Areas into four minor palaeogeographic territories: two surroundings (intermediate and Middle Sub-Baetic territories) and two ascendant areas, with sections belonging to the Upper Jurassic (external and internal SubBaetic) (Morgado \& Lozano 2014).

The primary geological flint outcrops analysed are located in the middle areas of the external Sub-Baetic areas. The Middle Sub-Baetic palaeogeography belonging to the Jurassic and the Cretaceous periods consists of a lithostratigraphic series structured in several sedimentary formations (Vera Torres \& Molina Cámara 1998). (Figure 4).

The flint of prime outcrop fits into the Veleta Formation, included in the Gaena Unit. This unit is an allochthonous set, which is on the Camarena-Lanchares Unit, separated from other sub-baetic units by Triassic materials that form the Gaena basis.

The Gaena Unit presents a dolomitic limestone set, which is divided into the Gavilán Formation, described as a dolomitic limestone set with Lower Domerian ammonites on its (upper part), the Zegrí Formation, which is composed of Domerian Middle-Aalenian and Veleta Formation marly limestones, marls and limestones, first described by Molina in 1987, and composed of pale grey folded limestone with abundant flint nodules and Lower AalenianBajocian bedrocks (Molina 1987).

The Veleta Formation has been the aim of our prospecting work since it is the most important formation with flint, and the closest one to the archaeological site. It has been prospected and sampled at six different points for subsequent petrographic analysis (Molina \& Vera Torres 1996), (Molina et al. 2004), (Figure 5). 


\begin{tabular}{|c|c|c|c|c|c|c|}
\hline \multirow{2}{*}{$\begin{array}{l}\text { Igneous } \\
\text { structures }\end{array}$} & \multirow{2}{*}{$\begin{array}{l}\text { Unidad Campo } \\
\text { de Gibraltar. }\end{array}$} & \multirow{2}{*}{\multicolumn{2}{|c|}{$\begin{array}{l}\text { Cordilleras Béticas. } \\
\text { Zonas Internas. }\end{array}$}} & \multirow{2}{*}{\multicolumn{2}{|c|}{$\begin{array}{l}\text { Cordilleras Béticas. } \\
\text { Zonas Externas. }\end{array}$}} & Macizo Hespérico. \\
\hline & & & & & & 23. \\
\hline 1. & 4. & 7. & 11. & 14. & 18. & 24. \\
\hline 2. & 5. & 8. & 12. & 15. & 19. & 25 \\
\hline 3. & 6. & 9. & 13. & 16. & 20. & 20 \\
\hline
\end{tabular}

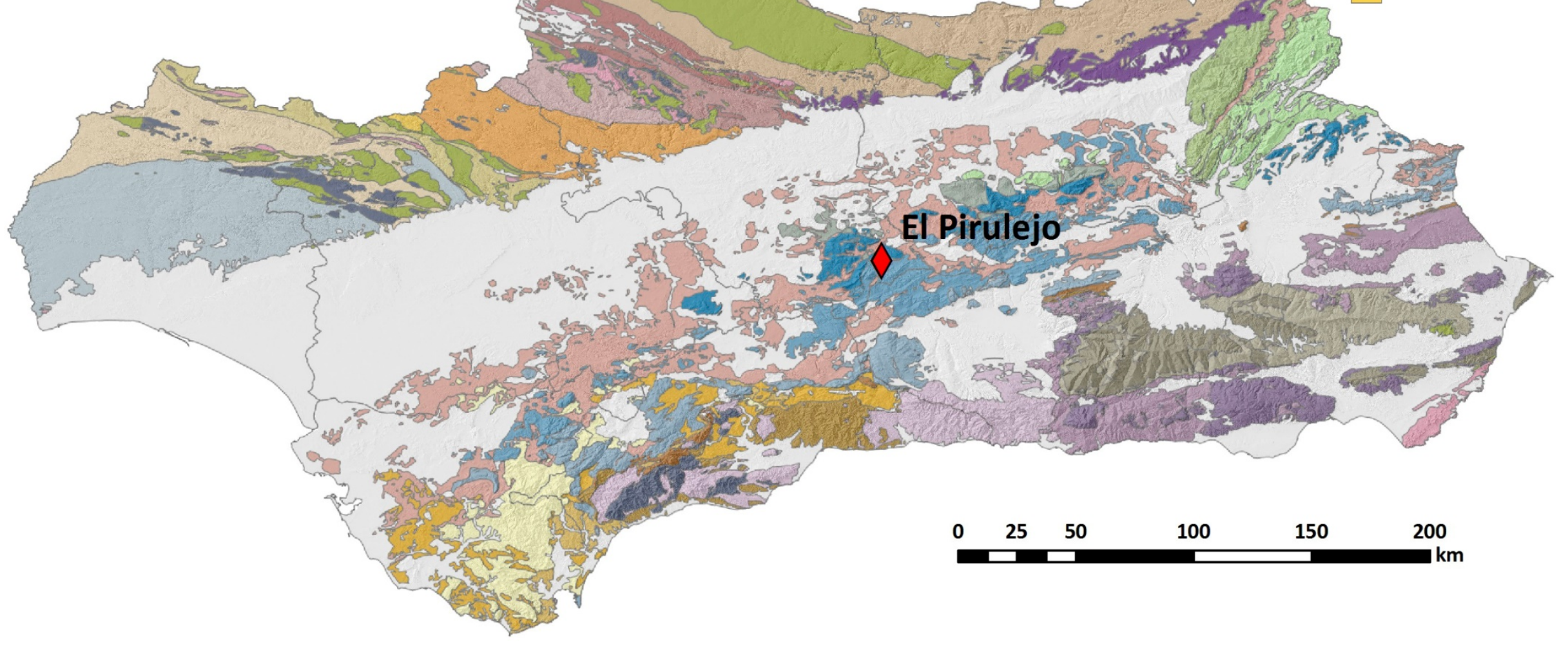

Figure 3. Geological maps. Baetic System based in Vera 2004. 1. Volcanic. 2. Basic Plutonics. 3. Acid plutonics. 4. Aljibe Unit. 5. Algeciras Unit. 6. Other Units. 7. NevadoFilabride Complex. 8. Nevado-Filabride Complex. Alpujarride Complex. 10. Alpujarride Complex. 11. Alpujarride Complex. 12 Malaguide Complex. 13. Dorsaliano Complex. 14. Internal Subbetic. 15. Subbetic Medium. 16. Subbetic External. 17. Intermediate Units. 18. Internal Prebetic. 19. External Prebetic. 20. Tabular Covarage. 21. Common Terms. 23. Area sub-portuguesa. 24. Central-Iberian Zone. 25. Sierra de Aracena Dominian. 26. Domain Elvas-Cumbres Mayores. 27. Domain OlivenzaMonesterio. 28. Domain Zafra-Alanis-Córdoba. 29. Sierra Albarrana Domain. 30. Domain Valencia de Torres-Cerro. 31. Obejo-Valsequillo Domain. 


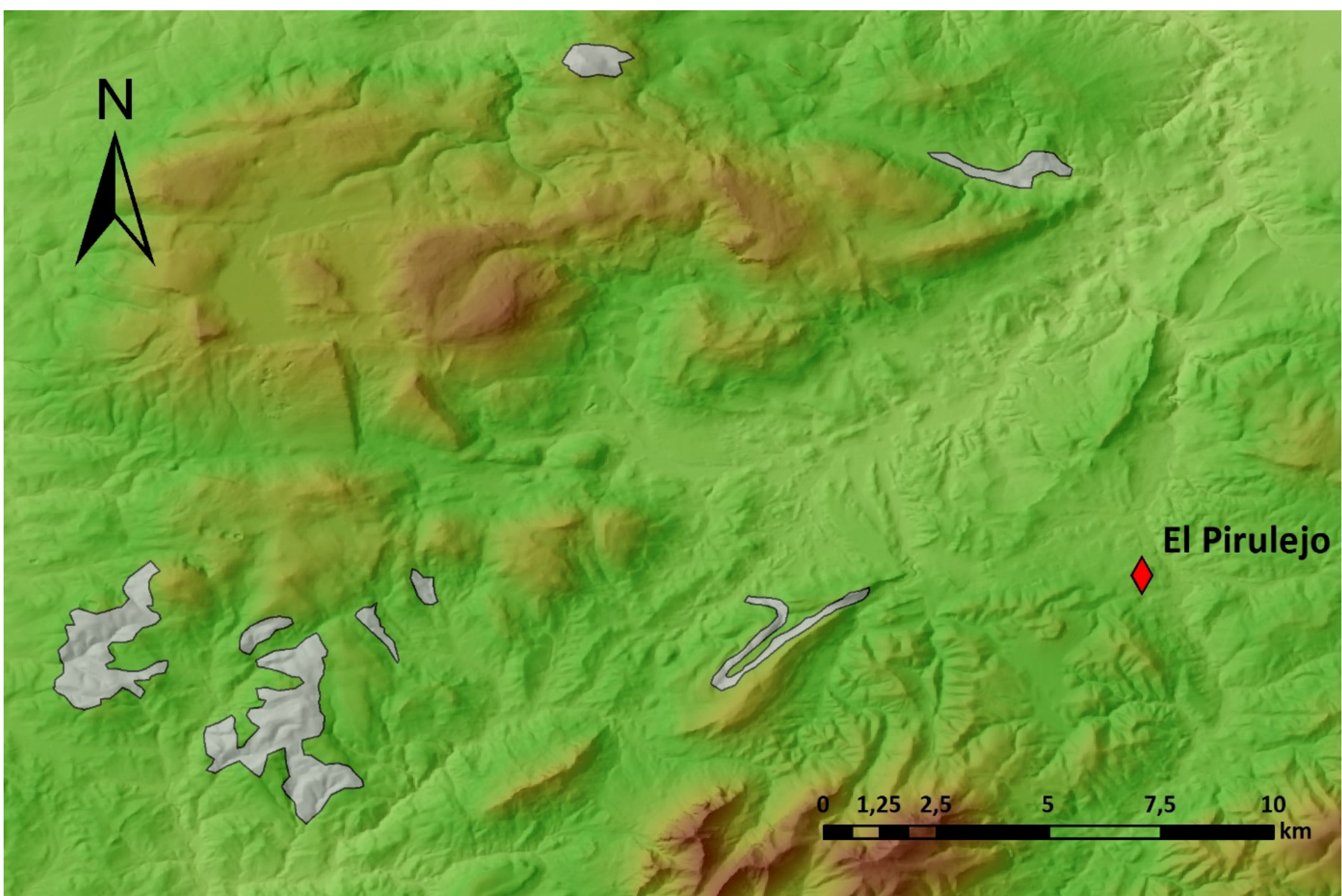

Figure 4. Maps of the Veleta Formation. Prospected areas. (Compiled by the authors.) 


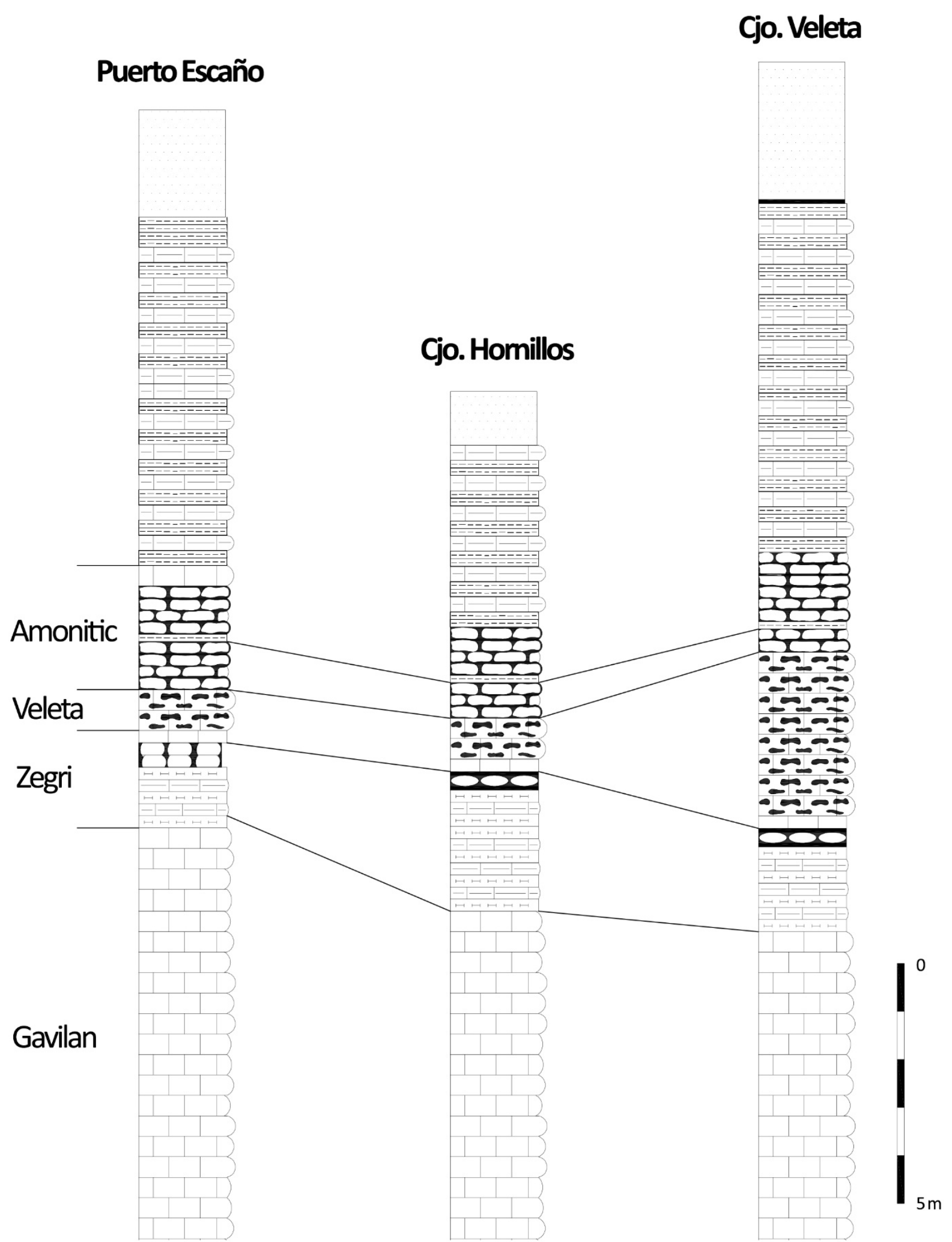

Figure 5. Stratigraphic columns of Gavilan, Zegri, Veleta and Amonitic Formation. (Prepared by the authors, based on Molina (1987).) The scale bar on is $5 \mathrm{~m}$ tall (divided into 1_ $\mathrm{m}$ sections). 


\subsection{Macroscopic and petrographic characterization}

\subsubsection{Geological flint}

From a macroscopic point of view, the geological flint shows a wide range of shades, from greyish to almost whitish. It is a semi-translucent flint, very jointed and fractured, ruling out a conchoidal fracture of the nodules found in primary outcrops (Figure 6).
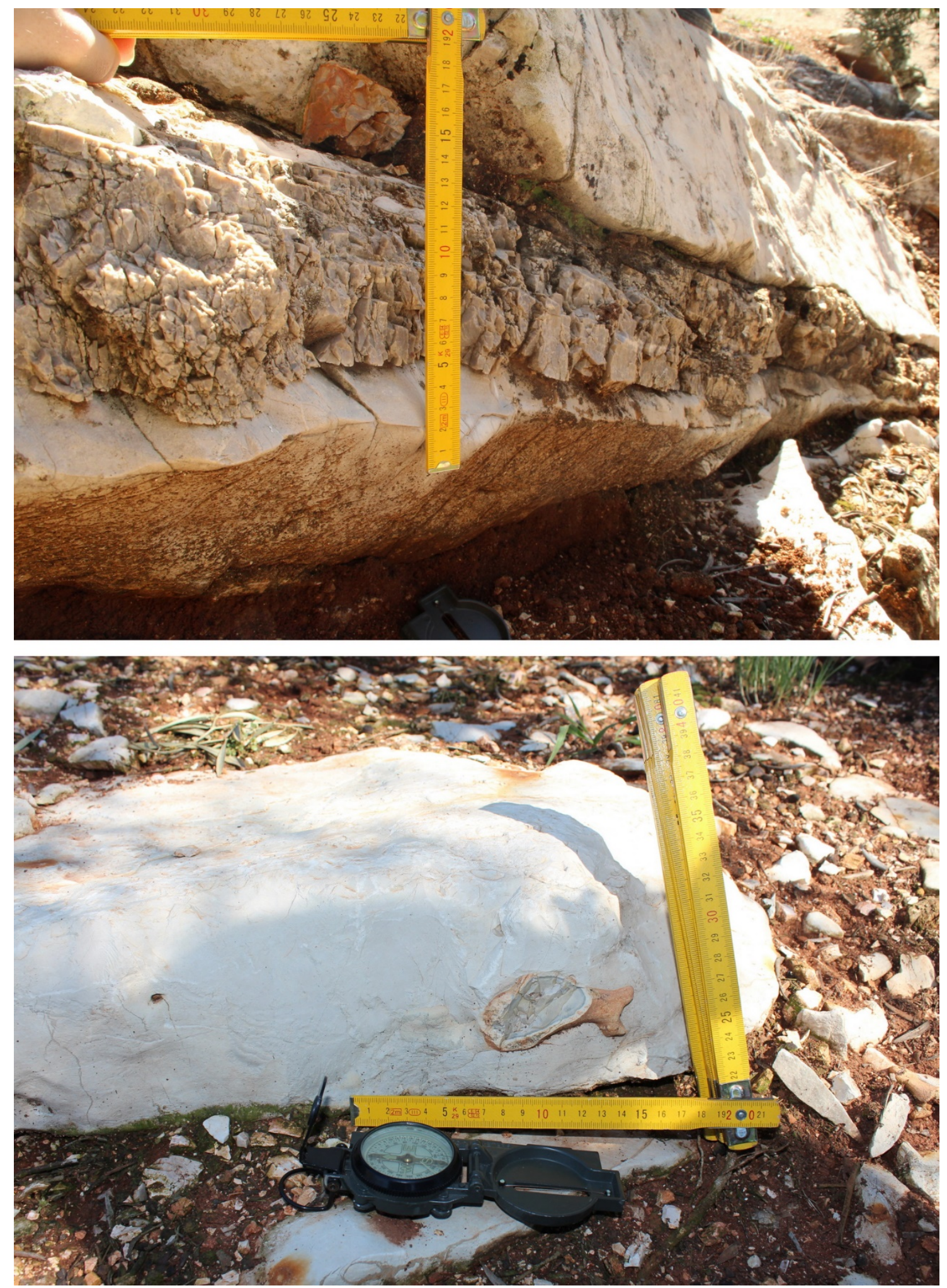

Figure 6. Primary outcrop of the Veleta Formation flint. Ruler segments are $20 \mathrm{~cm}$ each. 
The petrographic analysis identified a siliceous matrix formed by micro and cryptocrystalline mosaics with a packstone texture and radiolarians stuffed with recrystallized quartz, as well as pseudomorphs, and diagenetic dolomite crystals (see Figure 7). In addition, we observed lamination associated with radiolarians. The surfaces are not homogeneous, containing intraclasts in more carbonated areas, while more silicified parts were also observed.
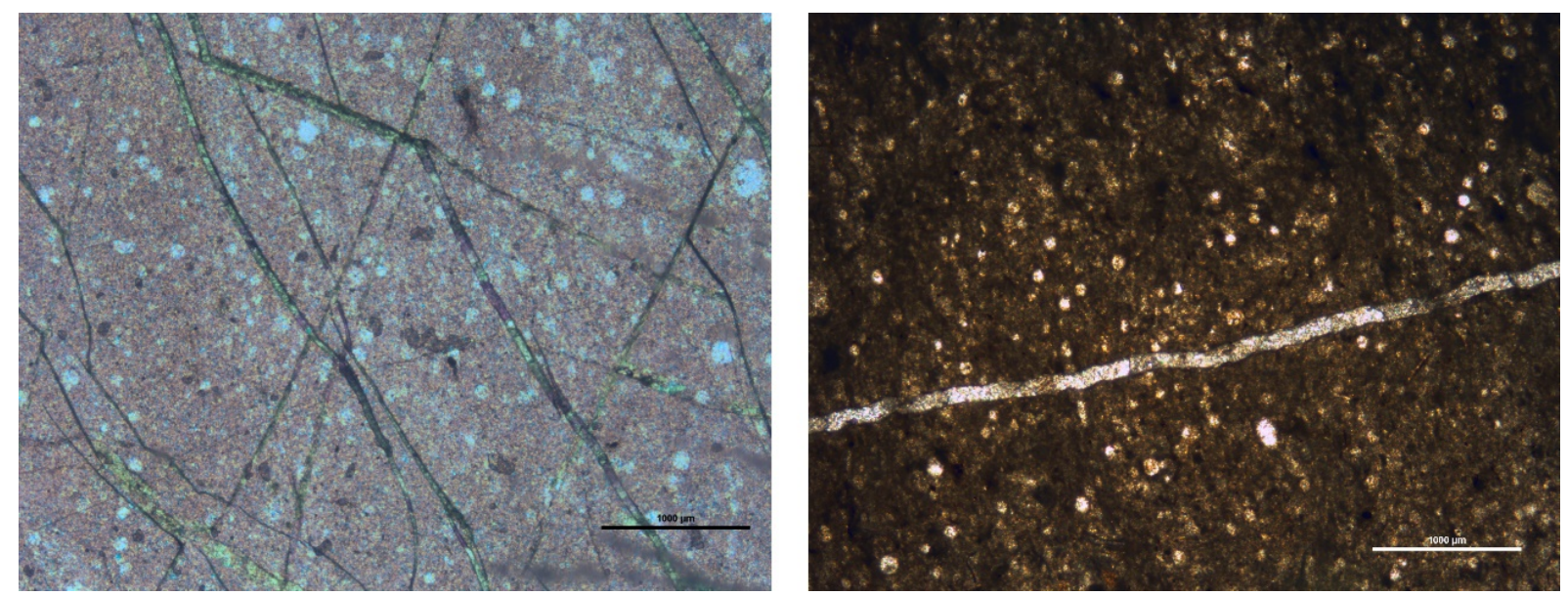

Figure 7. Geological flint. Petrographic analysis. (Crossed polarisers). Scale bars are $1 \mathrm{~mm}$ wide.

\subsubsection{Archaeological flint}

Observations obtained from the macroscopic and petrographic analysis of geological samples have been compared with the archaeological material.

Thus, we observe on the macroscopic analysis some siliceous varieties into the lithic assemblage of level P5 based on colour and texture.

\section{Radiolarites}

Yellowish and reddish radiolarites with a very compacted, shiny and opaque surfaces with a very fine grain, conchoidal fracture and absence of cracks and joints showing a distance from the macroscopic characteristics observed into the geological flint (Tucker 2009) (Figure 8).

In the microscopic analysis, we can observe cryptocrystals quartz an homogeneous and opaline matrix, with radiolarians. We observed a high concentration of iron oxides which provides the flint that peculiar colouring (O’Dogherty et al. 1997) (Figure 9).

\section{Chalcedonic flint}

It contains brown hues. This variety show a high level of transparency on the pieces, and a very fine grain compact texture and surfaces suitable for knapping (Figure 10).

In the petrographic analysis, we observed a cryptocrystalline texture in which flint replacement was carried out, with chalcedony crystals in a homogeneous micritic matrix (Figure 11).

\section{Grey radiolarite}

This one last variety of flint within the archaeological site corresponds to a grey flint, translucent at the edges and a very compact, shiny and conchoidal fracture surface. (Flörke et al. 1991), (Figure 12). 

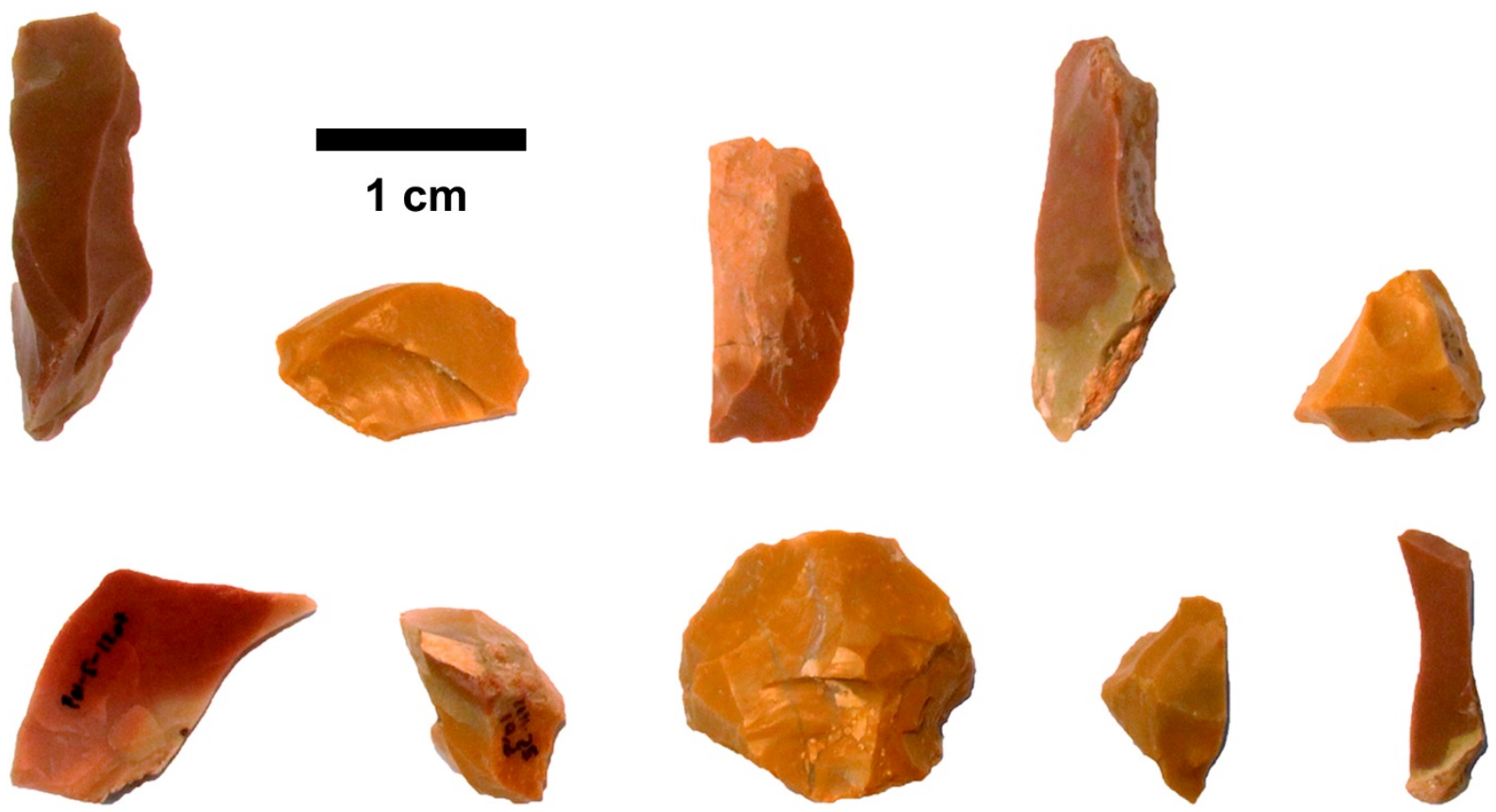

Figure 8. Radiolarites variety of the Pirulejo artefacts.
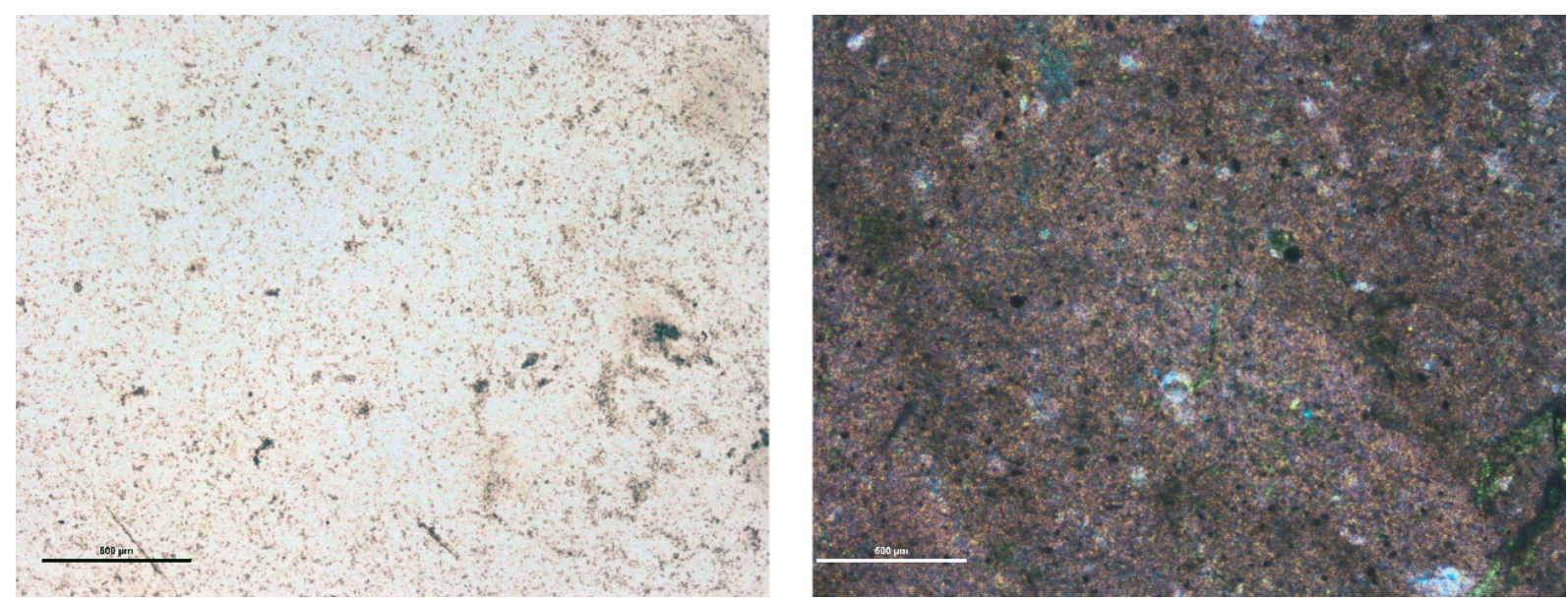

Figure 9. View of the petrographic analysis of siliceous variety radiolarites. (Parallel polarisers, left, X4. Crossed polarisers, right.) Scale bars are $500 \mu \mathrm{m}$ wide.

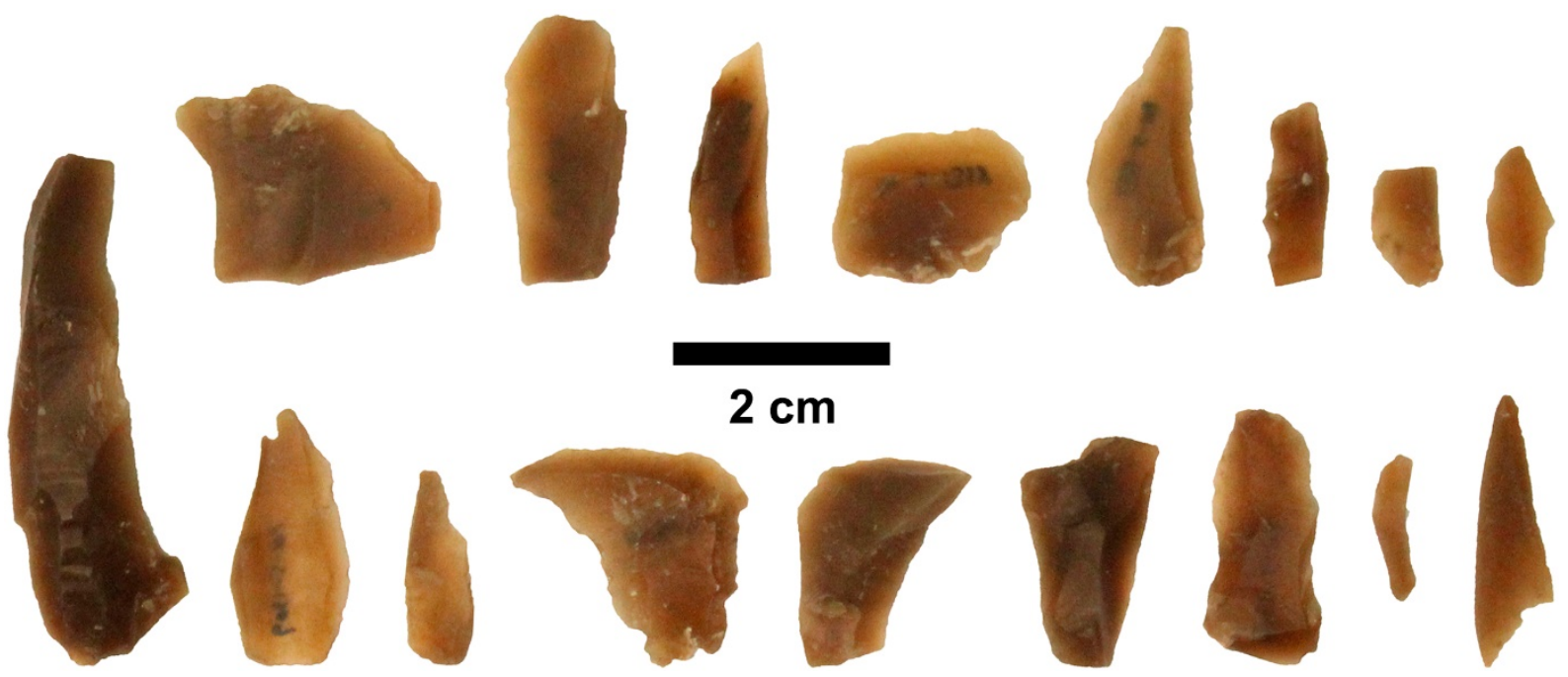

Figure 10. Translucent flint variety. 

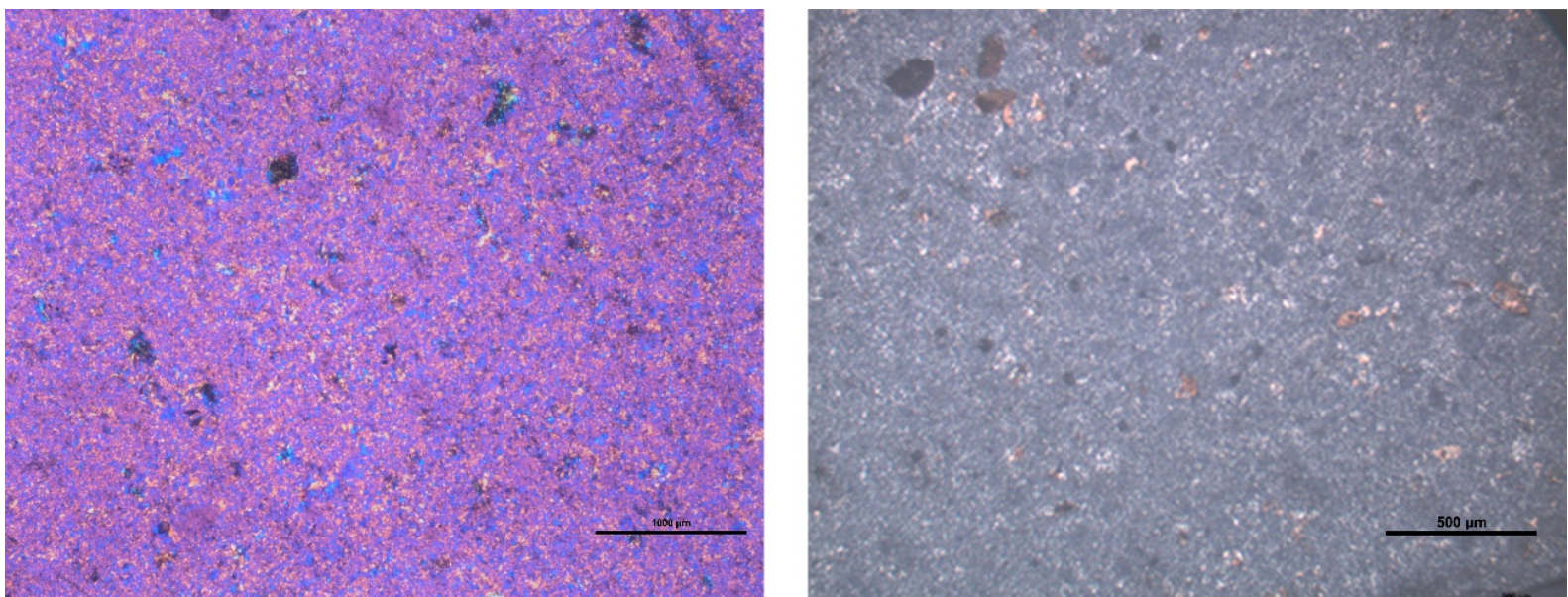

Figure 11. View of the petrographic analysis of the translucent flint. (Crossed polarisers.) The left scale bar is $1000 \mu \mathrm{m}$, the right is $500 \mu \mathrm{m}$.
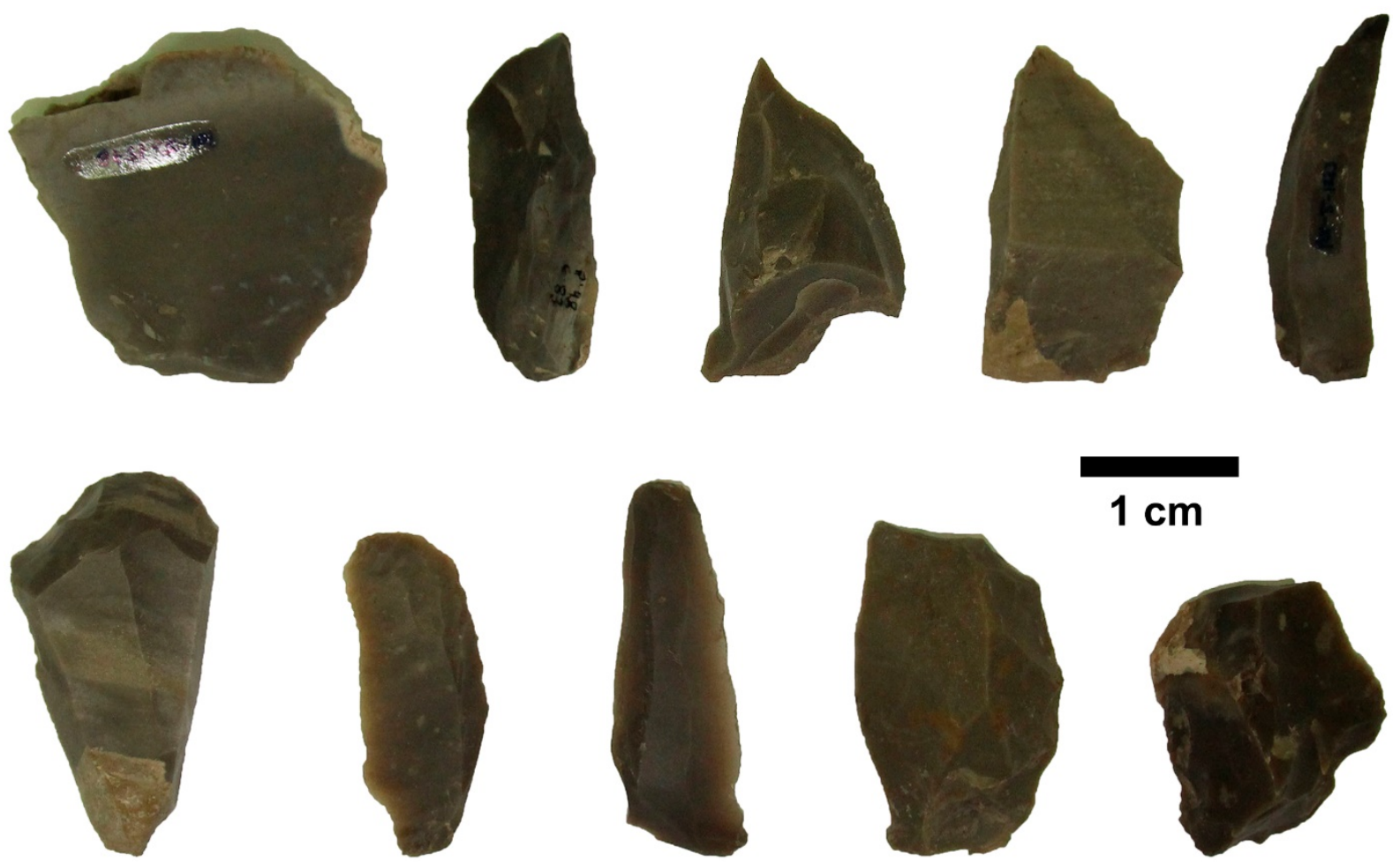

Figure 12. Grey flint variety.

As regards petrographic features we observed a very homogeneous, microcryptocrystalline silicified packstone texture flint. On the other hand, we observed a bioclastic texture with small undetermined spheroids features filled with opaque material and spheroid structures that could be identified as radiolarian (Figure 13).

\section{Discussion and conclusions}

The results of the comparison of macroscopic and petrographic analyses between the geological and archaeological flint indicate an absence of an exploitation of the Veleta Formation flint, which would be the closest flint contribution to the site.

The absence of this local flint in the archaeological assemblage of $\mathrm{P} / 5$ probably also responds to the jointed condition of the strata and siliceous nodules in this formation. These nodules do not have proper conchoidal fractures. 

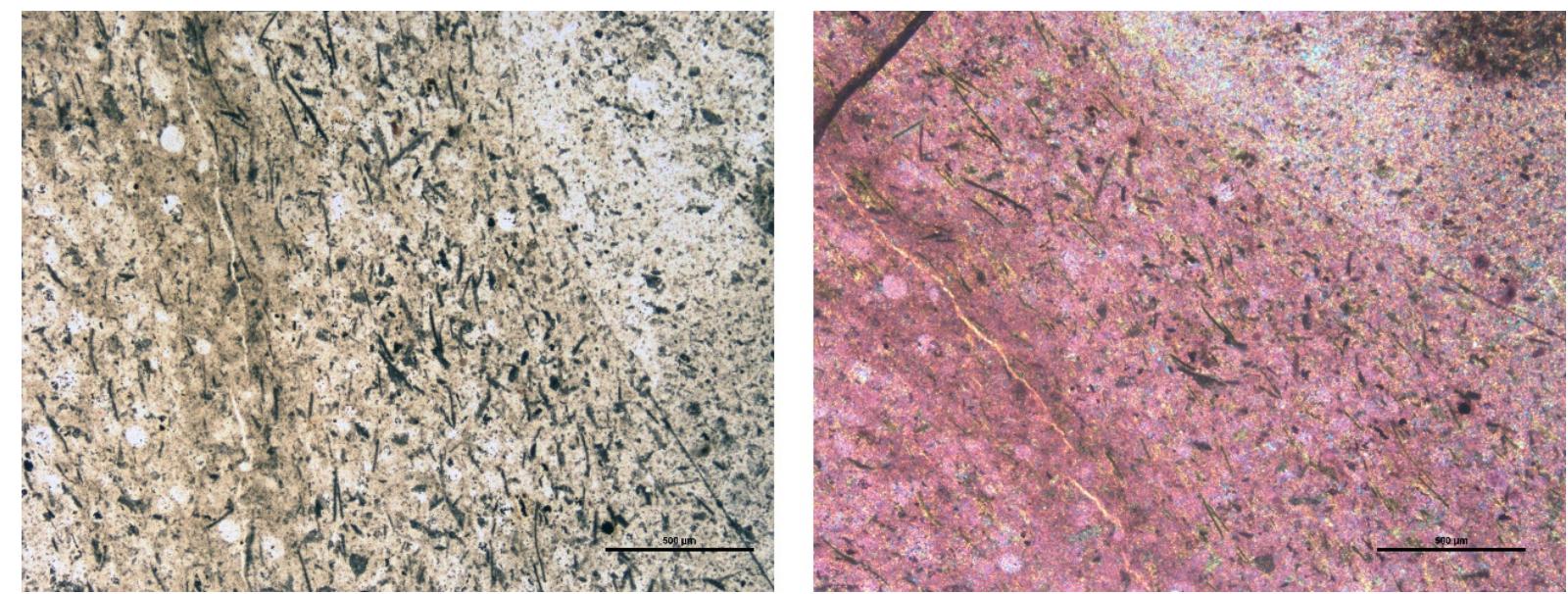

Figure 13. View of the petrographic analysis of the grey flint variety. (Parallel, left/crossed right polariser.) Scale bars are $500 \mu \mathrm{m}$ wide.

The flint observed in the archaeological site also has a compact and homogeneous surfaces without fractures, which allows diversity of knapping techniques to be used in the assemblage, mostly to produce bladelets and other retouched industry that demands different surface features then the ones the local Veleta flint presents.

So far, the best known sites in the South of the Iberian Peninsula are linked to coastal areas of Malaga and Algeciras, with an economic dependence on coastal ecotones. However, inland Andalusia should provide an important occupation. In addition, El Pirulejo and other less known sites as Mármoles, Murciélagos, Nacimiento or El Duende (Cortés et al. 2008), Vallespí 1969), (Turq 1992), show an important occupation during the Late glacial of inland Andalusia (Molina et al. 2004) (Figure 14).

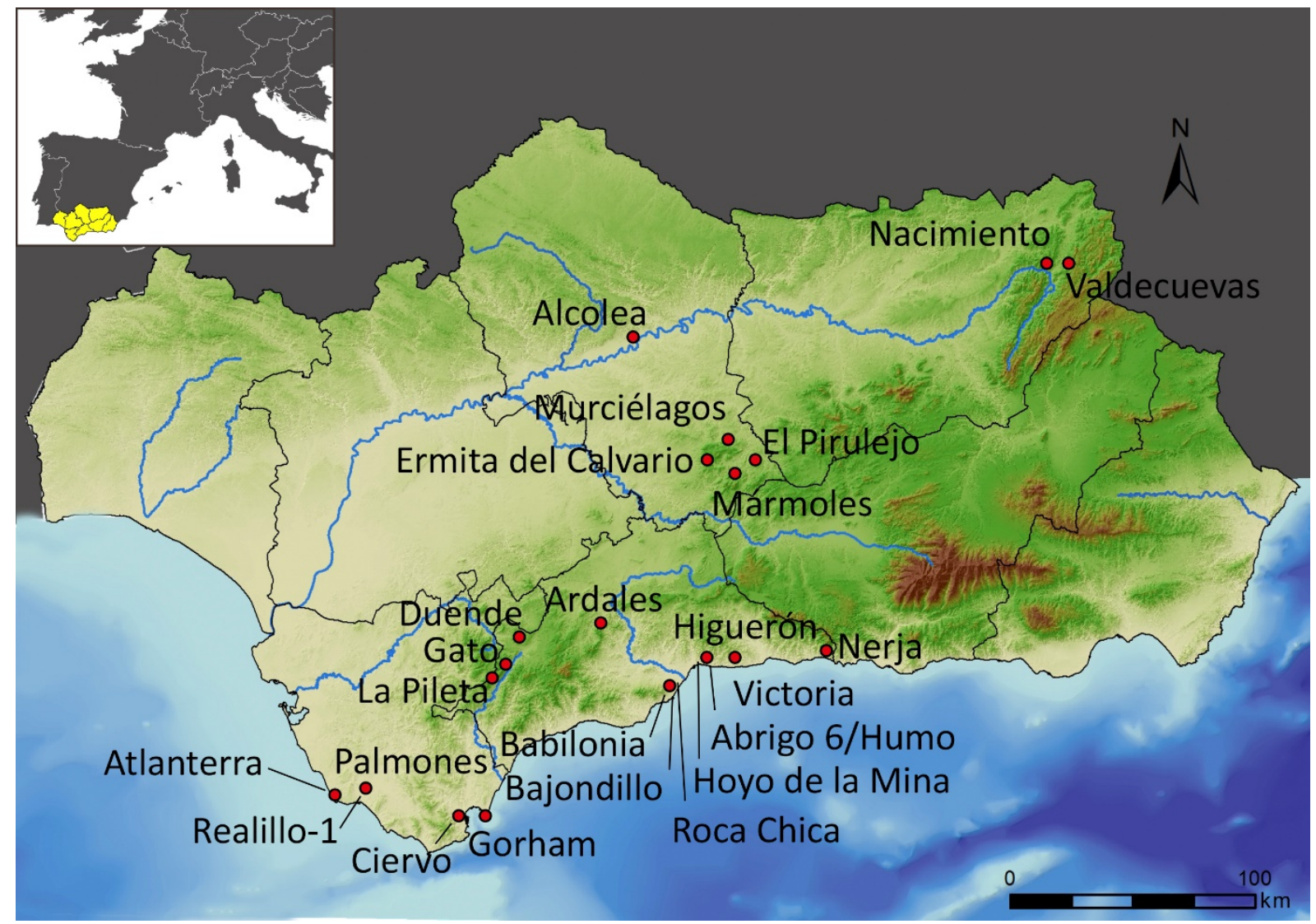

Figure 14. The site spread in the south of Spain. 
Preliminary data of our study suggest contacts between this centre and the coast, as it would reveal the important ornaments collection of sea shells in El Pirulejo.

Thus, we are working on the assumption that the area of mobility of hunter-gatherers societies in southern Iberia should polarize seasonal inner-coast movements.

This possibility is based on the analysis carried out so far on archaeological samples, which does not correspond with the petrographic features observed in flint categories in El Pirulejo area.

In conclusion, we dismiss a systematic outcrop exploitation within $20 \mathrm{~km}$ from the archaeological site and propose coast-interior exchange networks that we will be able to assess in the future with new prospecting and analytical works.

\section{Acknowledgements}

This study has been sponsored by Projects HAR2013-44269-P and HAR 2014-55722-P of the Spanish Ministerio de Economía y Competividad. The paper constitutes a contribution of Research Group HUM-949 (Tellus. Prehistoria y Arqueología en el sur de Iberia) and the Interdisciplinary Center for Archaeology and the Evolution of Human Behaviour. And thanks to Professor Adolfo Miras, of the Crystallography and Mineralogy department of University of Seville.

\section{References}

Álvarez F., Aldaya F. 1985, Las unidades de la zona Bética en la región de Águilas-Mazarrón (provincia de Murcia). Estudios geologicos, 41: 139-146. (in Spanish) ("The Baetic zone units in the region of Águilas-Mazarrón (province of Murcia)”) URL: http://estudiosgeol.revistas.csic.es

Cortés Sánchez, M. \& Simón Vallejo, M.D. 1997, Cueva Bajondillo (Torremolinos, Málaga). Aportaciones al paleolitico en Andalucía. In: El Món Mediterrani després del pleniglacial (18.000 - 12.000 BP): Col·loqui Banyoles, 1995 Vol. no 17, Sèrie monogràfica (Centre d'Investigacions Arqueològiques de Girona) Vol. 17, Museu d'Arqueologia de Catalunya, Girona: p. 275-290. (in Spanish) ("The Bajondillo cave (Torremolinos, Málaga). Contribution to the Andalusian Palaeolithic”)

Cortés, M., Asquerino, M. D. \& Sanchidrián, J. L. 1998, El Tardiglaciar en la cuenca del Guadalquivir. El caso del Pirulejo (Priego de Córdoba, Córdoba). In: Las Culturas del Pleistoceno Superior en Andalucía. Homenaje al profesor Francisco Jordá Cerdá (Sanchidrián Torti, J.L., Simón Vallejo, M.D., Eds.). Patronato de la Cueva de Nerja, Málaga: p. 157-178. (in Spanish) ("The Late Glacial in the Guadalquivir basin. The case of El Pirulejo (Priego de Córdoba, Córdoba). Upper Pleistocene culture in Andalusia”)

Cortés, M. 2007, Las industrias líticas del Paleolítico medio y superior, In: Cueva Bajondillo (Torremolinos). Secuencia cronocultural y paleoambiental del Cuaternario Reciente en la Bahía de Málaga (Cortés, M., Ed.). Servicio de Publicaciones del Centro de Ediciones de la Diputación de Málaga, Málaga: p. 171-446. (in Spanish) (“Lithic industries of the Middle and Upper Palaeolithic”, in: "Bajondillo Cave (Torremolinos). Chronocultural and palaeoenvironmental sequence during the Recent Quaternary in the Bay of Málaga”) 
Cortés-Sánchez, M. (coord. \& ed.) 2008, El Pirulejo en el contexto geográfico de la Subbética-Priego de Córdoba. Antiquitas, 20: 17-23. (in Spanish) ("El Pirulejo in the geographical context Subbética Priego from Cordoba”)

URL: https://dialnet.unirioja.es/servlet/articulo?codigo=2722942

Cortés-Sánchez, M., Morales-Muñiz, A., Simón-Vallejo, M. D., Bergadà-Zapata, M. M., Delgado-Huertas, A., López-García, Sánchez-Marco, A. 2008. Palaeoenvironmental and cultural dynamics of the coast of Málaga (Andalusia, Spain) during the Upper Pleistocene and early Holocene. Quaternary Science Reviews, 27(23): 2176-2193. doi:10.1016/j.quascirev.2008.03.010

Díaz del Olmo, F. 1995, Travertins mediterranéens à la fin du Quaternaire: la séquence de Priego de Córdoba (Andalousie, Espagne). Speleochronos, 6: 23-30. (in French) ("Mediterranean travertines of the Late Quaternary: the sequence of Priego de Córdoba (Andalusia, Spain)”)

Flörke, O. W., Graetsch, H., Martin, B., Röller, K., \& Wirth, R. 1991, Nomenclature of micro-and non-crystalline silica minerals, based on structure and microstructure. Neues Jahrbuch für Mineralogie Abhandlungen, 163: 19-42.

García, M., López, A., Rivas, P., Sanz de Galdeano, C., \& Vera, J.A. 1980, Mesozoic paleogeographic evolution of the External Zones of the Baetic Cordillera, Geololgie Mijnbouw, 59: 155-168.

Lozano, J.A., Morgado, A., Puga, E., Martín Algarra, A. 2010, Explotación del sílex tipo «Turón» (Málaga, España): localización y caracterización petrológica y geoquímica. Geogaceta, 48: 163-166. (in Spanish) (““Turón” type flint exploitation (Malaga, Spain): location and petrological and geochemical characterization”)

URL: http://hdl.handle.net/10272/7871

Mangado, J. 2006, El aprovisionamiento en materias primas líticas: hacia una caracterización paleocultural de los comportamientos paleoeconómicos. Trabajos de Prehistoria, 63(2): 79-91. (in Spanish) ("Supply of lithic raw materials: towards a palaeocultural characterization of the palaeoeconomic behaviour”) doi:10.3989/tp.2006.v63.i2.18

Molina, J.M. 1987, Análisis de facies del Mesozoico en el Subbético Externo (Provincia de Córdoba y Sur de Jaén). Doctoral thesis. Departamento de Estatigrafía y Paleontología, Universidad de Granada, Granada, 532 p. (in Spanish) ("Mesozoic facies analysis in the External Subbaetic (Province of Córdoba and south of Jaén”) URL: http://hdl.handle.net/10481/5945

Molina, J.M., \& Vera, J.A. 1996, La Formación Milanos en el Subbético Medio (Jurásico superior): definición y descripción, Geogaceta, 20(1): 39-42. (in Spanish) ("The Milanos Formation in the Middle Subbaetic (Upper Jurassic): definition and description”) URL: http://hdl.handle.net/10272/11403

Molina, F., Cámara, J.A., Nájera, T., \& Saéz, L. 2004, Los Millares y la periodización de la Prehistoria Reciente del Sureste. Report Number II \& III Simposios de Prehistoria Cueva de Nerja, Fundación Cueva de Nerja, Málagap: p. 142-158. (in Spanish) (“The Millares and the periodization of the Southeast Recent Prehistory") doi:10.2136/vzj2009.0027 
Morgado, A., \& Lozano, J. A. 2014. Objetos de sílex, marcadores litológicos de la circulación. Geoarqueología de la producción laminar especializada del sur de Iberia (c. VI-V mil. cal. BP). In: Movilidad, Contacto y Cambio: Actas del II Congreso de Prehistoria de Andalucía (Antequera, Málaga, 15, 16 y 17 de febrero de 2012) (García Alfonso, E. Ed.), Junta de Andalucía, Sevilla: 121-136. (in Spanish) ("Flint objects, lithological markers of circulation. Geoarchaeology of specialised laminar production in southern Iberia (c. $4^{\text {th }}-5^{\text {th }}$ millenium cal. BP”).

Morgado Rodríguez, A., Lozano Rodríguez, J.A., \& Pelegrin, J. 2011, Las explotaciones prehistóricas del sílex de la Formación Milanos (Granada, España). Menga: revista de prehistoria de Andalucía, 2(2011): 135-156. (in Spanish) ("The prehistoric exploitation of flint from the Milanos Formation (Granada, Spain)”)

Nocete Calvo, F. 2001, Tercer milenio antes de nuestra era: relaciones y contradicciones centro/periferia en el valle del Guadalquivir. Bellaterra Arqueología. Bellaterra, Barcelona, 187 p. (in Spanish) ("Third millennium BCE. Center/periphery relations and contradictions in the valley of the Guadalquivir")

O’Dogherty, L., Molina, J.M., Ruiz, P.A., Sandoval, J., \& Vera, J.A. 1997, La Formación Radiolarítica Jarropa: definición y significado en el Jurásico Subbético (Cordillera Bética), Estudios Geológicos, 53: 145-157. (in Spanish) (“The Radiolaritic Jarropa Formation: definition and significance in the Subbaetic Jurassic (Baetic System)”) doi:10.3989/egeol.97533-4239

Rodríguez-Tovar, F.J., and Uchman, A. 2010, Ichnofabric evidence for the lack of bottom anoxia during the lower Toarcian Oceanic Anoxic Event in the Fuente de la Vidriera section, Betic Cordillera, Spain. Palaios 25: 576-587. doi:10.2110/palo.2009.p09-153r

Tarriño, A. 2001, El sílex en la Cuenca Vasco Cantábrica y Pirineo Navarro:

Caracterización y su aprovechamiento en la Prehistoria. Tesis doctoral. Departamento de Mineralogía y Petrología, Facultad de Ciencias, Universidad del País Vasco, Leioa, 364 p. (in Spanish) ("The Flint in the Vasco Cantabrican basin and Pirineo from Navarra: Characterization and exploitation in the Prehistory”) URL: https://www.academia.edu/23193284

Terradas, X. 1998, La gestión de los recursos minerales: Propuesta teórico-metodológica para el estudio de la producción lítica en la Prehistoria. Rubricatum: revista del Museu de Gavà, 2: 21. (in Spanish) ("Management of mineral resources: theorical and methodologicalproposal for the study of lithic production in Prehistoric") URL: http://www.raco.cat/index.php/Rubricatum/article/viewArticle/196348/0

Turq, A. 1992, L'approvisionnement en matières premières lithiques du Magdalénien du Quercy et du Haut-Agenais: étude préliminaire. Documents préhistoriques, 2:301-308. (in French) ("The supply of lithic raw materials of the Magdalenian in Quercy and Haut Agenais: preliminary study. The Magdalenian format. Physical and human Palaeogeography")

Tucker, M. 2009, Sedimentary petrology: an introduction to the origin of sedimentary rocks (Third ed.). University of Durham. John Wiley \& Sons, Oxford, 251 p.

Vallespí, J.E., Ramos, J., Marín, E., Espejo, M.M., \& Cantalejo, P. 1988, Talleres líticos andaluces del Calcolítico y Bronce, Revista de Arqueología, 90: 14-24. (in Spanish) (“Andalusian lithic workshops during the Chalcolithic and Bronze Age") 
Vera, J. A. 1969, Características estratigráficas de la serie de Baza (Depresión de GuadixBaza, Cordilleras Béticas). Actas geológicas Hispánicas, 4(1): 14-17. (in Spansh) ("Stratigraphic characteristics of the Baza series (Guadix-Baza Depression, Baetic Cordillera”)

Vera, J.A., Molina, J.M. 1998, Shallowing-upward cycles in pelagic troughs (Upper Jurassic, Subbetic, Southern Spain), Sedimentary Geology, 119: 103-121. doi:10.1016/S00370738(98)00052-9

Vera, J.A. (Ed). 2004, Geología de España. Instituto Geológico y Minero de España (IGME), Madrid, 884 p. (in Spanish) (“Geology of Spain”) 